\title{
The Four Horsemen in Popular Culture
}

\author{
by Taylor Baugh, Ball State University
}

\begin{abstract}
This paper examines the popularity of the Four Horsemen within media today by looking at the television shows Supernatural and Sleepy Hollow. These two examples of Four Horsemen portrayals allow viewers to imagine a hopeful victory over the apocalypse that other depictions of apocalyptic events don't allow for. This paper studies the history of the Book of Revelation and its depiction in popular culture to better understand the importance of these optimistic outcomes in which apocalypse is averted.
\end{abstract}

\section{INTRODUCTION}

The Book of Revelation has always been a controversial text of the Bible. Many churches don't teach it, or they skim over it. In his book, Approaching Hoofbeats: The Four Horsemen of the Apocalypse, Billy Graham states, "Often in the history of the church the Book of Revelation has been neglected, misunderstood, or misinterpreted by far too many Christians” (18). Churches, while thoroughly examining much of the Bible, seem to ignore or put aside this specific book: throughout my research on this topic, I have talked to multiple churchgoers who do not know much about the Book of Revelation. So why does it play such a huge role in popular culture? I have encountered countless television shows, movies, books, and other forms of contemporary media that portray this biblical apocalypse in some way, and while Revelation has plenty to offer, much of the media focuses on only one of its key aspects: the Four Horsemen of the Apocalypse.

In portrayals of the Four Horsemen, screenwriters often depict them as tangible people, who are a main, if not the sole, cause of the apocalypse. In these interpretations, the main characters tend to have to fight the Four Horsemen and defeat them to stop the apocalypse. I believe the Four Horsemen are not only popular due to the prevalence of Christianity in the United States but also due to the fact that they are represented as a power that can be defeated. In other media about the apocalypse, the cause of the apocalypse tends to be actions that are difficult to prevent, such as global warming or incurable diseases. In the shows I examine in this paper, the Four Horsemen offer a chance 
for victory and a physical end to an apocalypse. In essence, popular depictions of Four Horsemen give our society a narrative hope that we need, which other forms of fictional apocalypse do not provide.

With much of our media being infused with negative stories about potentially apocalyptic terrors like nuclear war or climate change, this interpretation of the Four Horsemen creates optimism for our future. However, this may seem paradoxical, as our society doesn't want the events in the Book of Revelation to actually happen. It's something that frightens most people. Many churches don't focus on the book because it is such a negative text to study in comparison to many of the other books of the Bible, which offer a more positive message of forgiveness, hope, and joy. However, throughout time, various groups have read the Book of Revelation differently. Each denomination has their own insight into what the book is and how important it is to their followers. According to Robin Barnes, "Catholics generally accepted the book's canonicity but distrusted it, whereas Protestants were more actively devoted to defending it as a source of prophetic insight" (266). As we can see from these particular groups, the opinion on the Book of Revelation has always varied from one group to another. With these opinions being so different, it is easy to see the ways that different denominations may apply the Book of Revelation and the Four Horsemen to their lives and the world around them. These opinions on the Book of Revelation have not gone away and can be seen in the ways we address the book in our popular media today. However, contemporary media looks at the Book of Revelation from a different, more secular, perspective and with different expectations, both of which can facilitate a positive end to an apocalypse.

The actual Book of Revelation doesn't end with a seed of hope for our current world; rather, the book is filled with complete despair for the future of most of humanity. The current world we live in is completely destroyed, and the only hope left is in a place called New Jerusalem, a city where God has brought all of His faithful followers (King James Version, Rev. 21). There is so much destruction and despair in Revelation's apocalyptic world that it is not something that people would want to endure, and the focus of the text revolves closely around these horrors that humanity experiences. However, when Revelation's apocalypse is depicted within more secular shows like Supernatural and Sleepy Hollow, the focus is rather on preventing the destruction of our current world. With Christianity being so prevalent in American culture, it makes sense that shows like these would feature many depictions of and references from the Bible, but these portrayals of Revelation on television do not truly match those of the Bible, as these new portrayals, rather than stressing the terrors of an 


\section{BAUGH}

apocalyptic future, suggest that we shouldn't take such a gloomy view of the future too seriously. As these shows' apocalyptic interpretations demonstrate, people seem to be pushing against the gloomy biblical idea of apocalypse, wanting to believe instead that there is a way to survive. The screenwriters for these shows seem to be critiquing the Book of Revelation and those that take it too seriously by creating fantastical stories for their characters to fight through, and one way in which these screenwriters accomplish this is by humanizing the Four Horsemen. In essence, popular media is giving us an outlet to imagine a way out of such a terrifying end by depicting the Four Horsemen as conquerable beings. By looking at the history of the Book of Revelation and at the ways pop culture affects our society, as well as at examples of the Four Horsemen from Supernatural and Sleepy Hollow, I will be discussing this hope for human victory and survival that these depictions of the Four Horsemen provide.

\section{HISTORY OF THE BOOK OF REVELATION AND THE FOUR HORSEMEN}

When thinking about the Book of Revelation, it's important to note its origin and the origin of the Four Horsemen. According to Revelation itself, the book came about when John the Apostle recorded a vision given to him by God, upon which he sent the book to the seven churches of God (Graham 17-18). The Four Horsemen of the Apocalypse are introduced in Revelation 6:1-8, when the first four seals of the apocalypse are broken by the Lamb. The Four Horsemen each have their own significance and name: Famine, War, Pestilence or Conquest, and Death. The Four Horsemen ride out one-by-one as they are called by "the four living creatures" and as their respective seal is broken (King James Version, Rev. 6). The first Horseman carries a bow, wears a crown and is on a white horse; he is generally seen as Conquest, though some interpretations give him the name Pestilence. The second Horseman rides a red horse and represents War. The third rides a black horse and carries a pair of balances; he is given the name Famine. The final Horseman rides a pale horse and is given the name Death. This final Horseman is most popular within the television shows I analyze. In the Book of Revelation, there is no escape from the Four Horsemen. They are beings who cannot be stopped, and they will bring about the end of the world. However, in the television shows, they become physical beings who can be defeated in some way, the conquering of whom will stop the apocalypse from happening.

While the Four Horsemen have been around for a very long time, they gained popularity around the Reformation era in Europe (c. 1517 - 1648) due to their adaptability 
to the times. According to Barnes, the Four Horsemen were "popularized by Durer and especially Lucas Cranach in Martin Luther's German Bible” (263). One reason for their popularity is that the story of the Horsemen lends itself to much interpretation: people in the Reformation were able to take what the Four Horsemen represent and apply it to what was happening at that specific time. For example, some people of the Reformation believed that "[t]he white horse with its conquering rider stood for the Second Coming itself, and thus for the explosion of prophetic awareness and religious conflict sparked by the Reformation" (Barnes 263). Essentially, people during the Reformation Era believed that the Second Coming of Christ was upon them and that the white horse represented this event. Over time, the use of the Horsemen's adaptability has not changed. Much of Graham's book, which was written in 1985, is a call to action for Christians, and he uses the Four Horsemen as a way of explaining the things that will come if the world does not change. For example, when discussing the Horseman named War, Graham states:

This heavenly vision is God's way of showing us our folly and warning us of its consequences. Just as Harry Truman would not obey the warnings before Mount St. Helens erupted, so all of mankind through history has refused to listen to the warnings of God. (122)

Graham uses current events in tandem with interpretations of heavenly wrath as a way of influencing change among his readers. These are easy links to make: when reading the Book of Revelation, it is hard not to draw connections to current world problems, such as nuclear threats, global warming, and many pressing issues. This adaptability of Revelation and of the Four Horsemen allows readers and writers to apply these beings into stories easily.

However, it is not just in religious contexts that the Four Horsemen display their remarkable adaptability. In today's media, writers not only integrate the Four Horsemen into problems we are currently facing but also present them as conquerable forces. The Four Horsemen become physical beings with whom characters are able to interact and against whom they may eventually emerge victorious. The Four Horsemen in Supernatural and Sleepy Hollow have weaknesses - such as the ability to be injured by sunlight or the need for a ring to keep them in their physical form on Earth - that they don't have within the original text of the Bible. These weaknesses give humans a way to stop them from destroying the world. Unlike other types of apocalyptic threats depicted within popular media-threats such as plagues, zombies, and climate change, against which human survivors are struggling and lonely - the popularized depictions of the Four Horsemen allows for a more hopeful representation of apocalypse. Other apocalypses cannot be easily defeated, and many of 
them have become overwhelmingly real threats that our society could potentially face in the future. However, the Four Horsemen allow for a type of apocalypse that creates a more hopeful feeling in the end. In shows like Supernatural and Sleepy Hollow, the audience is better able to envision a future in which the apocalypse and the evil in the world have been stopped. We are given an opportunity to be more optimistic while watching the Four Horsemen's depictions in these shows than when we contemplate the frightening future the Bible provides us. With so much of our media obsessing over the horrors of our present world, this optimistic portrayal of the Four Horsemen offers viewers the chance to imagine a positive future, which creates the kind of hope our society needs. If viewers are shown the end to an apocalypse, this could potentially encourage them to have confidence in our world and to want to work to fix the problems we are facing. By giving us hope within a television show, the positive apocalyptic story of the defeat of the Four Horsemen has the potential to give us faith within our reality as well. In a society that obsesses over the myriad of awful potential futures we face, such a positive apocalyptic story is rare.

\section{REVELATION AND POPULAR CUTURE}

Popular culture is deeply influential to society. In his book Pop Culture Wars: Religion \& the Role of Entertainment in American Life, William Romanowski recalls a time when he was on a trip in Philadelphia with a youth group just after the release of the first Rocky Balboa film. The students he was with were not as interested in the normal tourist sights but rather the places seen in the film. Romanowski states:

Most of all, they wanted to visit the Philadelphia Museum of Art. They were not, however, the least bit interested in the museum's striking Greek Revival architecture or the priceless collection of art housed inside. What they wanted to see was the museum's steps - all seventy-two of them. When we arrived at this major artistic institution, these young people jumped out of the vans and raced up the huge stone steps, their own personal recreation of Rocky's energizing run as he prepared to fight for the heavyweight championship of the world. (9-10)

This story shows how pop culture can influence a person's view of the world around them.

The museum's meaning completely changed for the fans of this movie. The steps became an iconic place to visit and see just what Rocky saw as he prepared for the championship. This shows how pop culture exerts a very strong force upon our minds. This is no different when it comes to the apocalyptic thought surrounding our pop culture.

Many scholars have attempted to classify the different futures contemporary media 
portray. One scholar, Alan Clardy, states that there are six types of futures that we imagine within pop culture. As Clardy says, "Indeed, as argued here, six visions of the future can be found in popular culture, and each one presents a fundamentally distinctive conception of the world to come" (37). These six futures include: progress and utopia, the anti-utopian nightmare, dystopia, conflict and resolution, collapse, and apocalypse. Clardy states there have been previous attempts at categorizing these futures; however, the ones Clardy delinieates are separated even further into smaller categories. Each of these categories has specific histories and characteristics that define them. While many people use the term apocalypse to classify anything dealing with the potential end of the world, Clardy has a very specific definition. Clardy states: "In all of these manifestations, the paradigm of apocalypse shares several defining features. First, the end of this mortal world is ordained to arrive soon, often at a time predicted in great detail. Second, knowledge of this inevitable future has been obtained from extra-human, archaic, or divine sources and the prophecy revealed is doom" (44). With this sort of thinking, an apocalyptic future in pop culture becomes much more limited in its definition. While there are quite a few shows, books, and movies that discuss the end of the world, Clardy's definition of apocalypse changes just how many can be classified as apocalyptic. However, this narrower definition does not change the fact that our society is very focused on the destruction of our world. In fact, the classifications of futures that Clardy presents show just how prominently current media is fixated on the future and the end of the world, and it undoubtedly can be discouraging for viewers to see these constant depictions of destruction without a type of buffer. However, modern depictions of the Four Horsemen offer a refreshingly hopeful alternative to this constant barrage of future negativity. While other apocalyptic narratives seem hopeless, these portrayals of Four Horsemen offer the chance for victory and survival. The popularity of the Four Horsemen is understandable when looking at the different types of futures Clardy describes, as, within his definition of the term apocalypse, the Book of Revelation is one of the few depictions that still fits the definition. However, the Four Horsemen are also popular because they offer viewers something that many other apocalypses do not: a way out.

Clardy is not the only scholar to point out how much of our media deals with potential futures; James Berger also discusses our society's attachment to apocalyptic depiction, and he too offers potential insight into why our society might enjoy our modern depictions of the Four Horsemen. When talking about the apocalypse, Berger states:

To think that everything really is over would be a great relief, and a positive satisfaction. So many self-righteous and complacent individuals and institutions 
would get their comeuppance in a hurry. Except that it has already happened. What will happen has happened, is happening. But the world is still here exactly as it was: that is what is intolerable. And therein lies the pleasure in imagining its destruction, and the horror and confusion in reflecting that such enormous, such definitive catastrophes have actually and in the flesh taken place. (32)

Berger is explaining that there is a pleasure in imagining the end of the world because at the end of the apocalypse there would be no more responsibility, and everything and everyone that had ever done something wrong to a person would be gone or would have gotten its punishment. However, I believe that, while people do enjoy imagining the apocalypse to a certain extent, there comes a point where people may want to think of a future without a destructive end. It begins to weigh on viewers' shoulders just how real these potential futures may be. Here too, the modern apocalypse of the Four Horsemen can offer a tantalizing alternative: while it gives viewers a chance to contemplate the end of the world, it also allows for the world to be saved. We want to imagine the end but we don't really want the world to end. The Book of Revelation doesn't offer believers much chance for optimism about our future in this world; however, this story has shifted within popular media to illustrate a way out. With Christianity being so prevalent in our society, we want to address this terrifying prophecy but shift it in a way that gives us an opportunity for more optimism.

Since Christianity plays such a large role in our culture, it can be easy to see why a book like Revelation would largely influence different media. According to Ericka Engstrom in the book Television, Religion, and Supernatural: Hunting Monsters, Finding Gods,

$[w]$ hen one considers the religious identification of the U.S. population, U.S.

Census Bureau figures illustrate that most adults self-identify as Christian, and of those, most report describing themselves as Protestant. The latest census figures, from 2008, show that among some 228 million adults, more than 173 million (75\%) identified themselves as belonging to some form of Christian religious group. (6) This shows just how prominent the Christian religion is within America, and this has a large impact on the pop culture of America. However, there are many cultures fascinated by religion and apocalypse in addition to America; in the article, "Apocalypticism and Popular Culture in South Africa: An Overview and Update," Margaret Mollet argues that the reason millennial dispensationalism (belief that scripture is prophecy and is used to decide where a person is within the timetable of the Bible) is so embedded within people's minds is because of the influence pop culture has on its audience. This argument could also be made for apocalyptic thought being so prominent in American society today. There seems to be a 
cyclical pattern of apocalyptic thought and of pop culture's use of the apocalypse. With each wave, the apocalypse becomes more and more embedded into our society. The role of the Four Horsemen within pop culture today is much the same of apocalypse as a whole.

With religion being such a strong force in America, it makes sense that it would influence our popular culture to some degree. This influence can be seen in our continuous representations of the future. With popular culture having such an influence over us, screenwriters of shows like Supernatural and Sleepy Hollow may be attempting to influence viewers to be more proactive in confronting the often-immobilizing threats against our world. These shows, while they are more unrealistic, seem to be calling viewers to act upon their fears of the world ending. The screenwriters want us to fight the "Four Horsemen," or our potential future apocalypses, just as their characters do.

There are quite a few mentions of the Four Horsemen in pop culture through songs, movies, books, and television shows. The television shows Supernatural and Sleepy Hollow are just a couple examples of the utilization of the Four Horsemen in pop culture. Both of these contain the Four Horsemen in different interpretations, but the Horsemen are still contributing to the apocalypse in some way. By looking at both of these representations, we can see how the Four Horsemen are used in pop culture, and we can understand the sense of hope they create for the audience.

\section{SUPERNATURAL AND SLEEPY HOLLOW ANALYSIS}

Supernatural, a CW television show that is currently in its thirteenth season, follows two brothers, Sam and Dean, on their journey fighting monsters of all kinds, including vampires, wendigos, demons, ghosts, angels, and even Lucifer himself. While the Four Horsemen don't appear until Season Five, their story arc begins at the end of season four, where the show leaves off with Sam and Dean inadvertently breaking the last of the show's 66 apocalyptic seals by killing the demon, Lilith, an action that starts the apocalypse by allowing Lucifer to rise from his cage. As the apocalypse begins in Season Five, Sam and Dean are told that they are to become the vessels of Lucifer and the archangel Michael, entities who will ultimately fight to decide the fate of the world. Throughout the season, Dean refuses to allow Michael to use him as a vessel, and Lucifer begins to use the Four Horsemen to destroy the world. The Four Horsemen, who are shown without horses and as older men, show up one by one just as they do in the Book of Revelation: first War, then Famine, Pestilence, and, finally, Death. Sam and Dean learn that, in order to stop Lucifer, they need the ring of each Horseman to open Lucifer's cage again and trap him once more. 


\section{BAUGH}

Throughout the season, they encounter and fight War, Famine, and Pestilence and get their rings. (In the show, the Horsemen are unable to be killed, but without their respective rings, they cannot manifest a physical form on Earth or use their power). Finally, Dean makes a deal with Death and receives the final ring needed to carry out the plan to stop Lucifer and the apocalypse. When talking to Death, Dean learns that Death is enslaved to Lucifer and wants to be free, a situation that prompts the Horseman to help Sam and Dean defeat Lucifer and stop the apocalypse. While Dean does have to make a false promise to Death, saying that he will do whatever it takes to put Lucifer in his cage, even allowing Sam to fall into the cage as Lucifer's vessel, there is an expectation within this scene that they will be able to stop the apocalypse from happening.

Throughout the fifth season of Supernatural, Sam and Dean face all Four Horsemen and defeat or work with them one by one. This sort of story creates a hope that they will stop the apocalypse and put Lucifer back in his cage before the world ends. Even at the end of the season when Sam falls into Lucifer's cage with him in order to stop him, Sam and Dean's strong, brotherly bond constantly promises viewers that there is always a chance of bringing the other back when it seems impossible. In the next season, Dean visits Death again and asks him to bring Sam back from Lucifer's cage. Death agrees to do this if Dean retrieves his ring, which Dean did not return after borrowing, and wears it for a day to see what it is like being Death. He does this to show Dean just how hard his job is and how much it takes out of him. This shows the audience that Death isn't necessarily all bad and has a conscience just as we do-in this interpretation at least. While watching this unfold, the audience is able to see the Four Horsemen as not only conquerable but also as beings who have feelings like ours. It humanizes the entire storyline and allows for the audience to imagine the end of the world while still imagining ways to prevent this disaster from actually happening. The physical beings of the Four Horsemen offer a more positive ending to the apocalypse.

Another example of the Four Horsemen within pop culture is in the television show Sleepy Hollow. Season One opens in 1781 with Ichabod Crane on a mission for George Washington to kill a Hessian soldier with a bow and arrow tattoo on his hand. Ichabod finds the Hessian and, upon fighting him, is fatally injured; however, he is able to decapitate the soldier just before he dies. In the next scene, Ichabod wakes up in the year 2013, close to the same time the Headless Horseman does. The Horseman begins to kill throughout the town of Sleepy Hollow, and Ichabod is brought in by the police as a suspect. At the police station, Ichabod tries to explain who he is, and who the Horseman is, but no one takes him seriously 
except one person-Lieutenant Abbie Mills. Her partner was killed by the Horseman, and after Ichabod describes the Horseman perfectly to her, she decides to listen to him. Soon the two begin to work together to figure out how to stop the Horseman. As the show progresses, the two learn that the horseman is actually the Horseman of Death from the Book of Revelation and that he plans on raising the other three Horsemen to begin the apocalypse. Abbie and Ichabod learn that they are the two witnesses that the Bible describes and are destined to stop the apocalypse and protect Sleepy Hollow. Throughout the show, Ichabod and Abbie begin to learn more about who the Horseman is and how to stop him.

In the end, they realize that the Horseman has a weakness to sunlight or UV lights, and, by exploiting this weakness, they are able to take the Horseman prisoner so that he can no longer try to raise the other three Horsemen. Just like in Supernatural, the audience is able to picture an oncoming apocalypse while still entertaining the possibility of victory and of a happy ending.

Both of these shows offer viewers more than just the chance to imagine the apocalypse; they offer the chance to hope for the world. The Four Horsemen in each of these examples are physical beings, able to be defeated by humans. The physical manifestation of the apocalypse allows for the audience to better visualize an actual end to the potential of apocalypse. These shows seem to be a call to action for viewers, for even if these are not realistic visions of our future, the Four Horsemen are a symbol for more realistic threats to humanity. The writers are calling for viewers to want a future for our world through these shows and their depiction of defeating the Four Horsemen.

Supernatural and Sleepy Hollow give viewers an opportunity to envision a future that they have control over. The writers for these shows seem to be offering the audience the chance to see their agency in the future of their world by depicting humans as the ones defeating the apocalypse. The Four Horsemen are a prominent cause of the apocalypse in media, but their role differs from other apocalyptic figures presented by the media. While much of contemporary media does deal with potential futures of our world, these futures tend to be more pessimistic with no way to stop the apocalypse from happening. In many of these portrayals, there are few survivors and little confidence of bringing the world back to what it once was. Within Supernatural and Sleepy Hollow, however, we are able to experience a different type of future. These shows offer a different telling of this story, one in which the human characters are able to defeat the Four Horsemen and stop the apocalypse. These television shows change the Book of Revelation to offer a more optimistic conclusion, which gives the viewers hope for their future. While Christianity being popular in the United 
States plays a large role in the reasoning behind our portrayals of the Four Horsemen, I believe that our wish for a better future plays an even bigger role in the popularity of these interpretations, as media like Sleepy Hollow and Supernatural gives the audience a chance to envision a future that is no longer being plagued by the thought of impending doom. I believe these shows are asking viewers to see that humans are the ones who can stop the apocalypse; we just have to acknowledge this responsibility and work toward a better future. Rather than presenting apocalypses that seem unstoppable and give viewers a pessimistic view of the future, viewers are given a reason to hope. This want for a better future is what our society needs, and that is what makes these types of depictions so important.

\section{WORKS CITED}

Barnes, Robin B. "Varieties of Apocalyptic Experience in Reformation Europe." Journal of Interdisciplinary History, vol. 33, no. 2, Sept. 2002, pp. 261-274. EBSCO host, doi:10.1162/00221950260208706.

Berger, James. After the End: Representations of Post-Apocalypse. University of Minnesota Press, 1999.

Clardy, Alan. "Six Worlds of Tomorrow." World Future Review (World Future Society), vol. 3, no. 2, Summer 2011, pp. 37-48. EBSCOhost, proxy.bsu.edu/login?url=http://search. ebscoho st.com/login.aspx?direct=true\&db=aph\&AN=69646036\&site=ehost-live\& scope $=$ site.

Engstrom, Erika. Television, Religion, and Supernatural. Lexington Books, 2014.

Graham, Billy. Approaching Hoofbeats: the Four Horsemen of the Apocalypse. Word Books, 1985.

Iscove, Phillip, et al., creators. Sleepy Hollow. Sketch Films, K/O Paper Products, and Twentieth Century Fox Television, 2013.

Kripke, Eric, creator. Supernatural. Kripke Enterprises and Warner Bros. Television, 2005. Mollett, Margaret. "Apocalypticism and Popular Culture in South Africa: An Overview and Update.” Religion \& Theology, vol. 19, no. 3-4, Sept. 2012, pp. 219-236. EBSCOhost, doi:10.1163/15743012-12341240. 
Romanowski, William D. Pop Culture Wars: Religion \& the Role of Entertainment in American Life. InterVarsity Press, 1996.

The Holy Bible. King James Version, Zondervan, 2002. 